\title{
Differentiation of BMSCs into Nerve Precursor Cells on Fiber-Foam Constructs for Peripheral Nerve Tissue Engineering
}

\author{
Tugba Dursun Usal ${ }^{a, b}$, \\ Deniz Yucel ${ }^{\mathrm{a}, \mathrm{c}}$ and Vasif Hasirci ${ }^{\mathrm{*a}, \mathrm{b}}$ \\ ${ }^{a}$ Middle East Technical University (METU), BIOMATEN \\ Center of Excellence in Biomaterials and Tissue Engineering \\ 1 Dumlupinar Blvd., Ankara, 06800, Turkey \\ ${ }^{b}$ METU, Department of Biological Sciences \\ 1 Dumlupinar Blvd., Ankara, 06800, Turkey \\ ${ }^{c}$ Acrbadem University \\ 32 Kayisdagi Str., Kerem Aydinlar Campus, \\ İcerenköy Mahallesi, Atasehir, İstanbul, 34752, Turkey
}

Received 22.02.2018, received in revised form 21.04.2018, accepted 19.05.2018

Bone marrow stem cells (BMSCs) are frequently used in nerve tissue engineering studies due to ease of their isolation and high potential for differentiation into nerve cells. A bilayer fiber-foam construct containing nanofibrous elements to house and guide BMSCs was designed as a model to study the regeneration of damaged peripheral nerve tissue and eventually serve as a nerve guide. The construct consisted of a) a macroporous bottom layer to serve as the backing and support, and for nutrient transport, and b) an electrospun, fibrous upper layer for cell attachment and guidance. Porosity and pore sizes of poly(3-hydroxybutyrate-co-3-hydroxyvalerate) (PHBV) bottom layer were $85 \%$ and 5-200 $\mu \mathrm{m}$, respectively, suitable for cell attachment and growth. Alignment of the cells is essential for cell-to-cell contact and the degree of alignment of electrospun PHBV/Collagen fibers was $11^{\circ}$ when a frame type collector was used, while it was much higher $\left(53^{\circ}\right)$ for random fibers produced on an ordinary aluminum sheet collector. When the fibers were electrospun directly onto a PHBV foam attached on the frame type collector to create the bilayer, the degree of alignment of fibers decreased, alignment angle increased from $11^{\circ}$ to $44^{\circ}$. This value did not change when the fibers were electrospun directly on the foams on the aluminum collector $\left(53^{\circ}\right.$ vs $\left.55^{\circ}\right)$. A new media was designed to achieve comparable differentiation with the commercial media. It was found that the commercial Mesenchymal Stem Cell Neurogenic Differentiation Medium (PromoCell, Germany) was the better in terms of the expressions of neuronal markers nestin and $\beta$-III tubulin and the medium made in the lab with known constituents led to neuronal marker expressions very close to that with the commercial

(C) Siberian Federal University. All rights reserved

* Corresponding author E-mail address: vhasirci@metu.edu.tr 
medium. Attachment and proliferation of the rBMSCs were higher on the random fiber mats, while alignment of cells was higher on the aligned fibers. In conclusion, the bilayer construct with aligned PHBV-collagen fibers on a PHBV foam was found to be more appropriate for peripheral nerve repair when used as a nerve guide.

Keywords: bone marrow stem cells, nerve tissue engineering, peripheral nerve regeneration, nanofibrous mats, nerve guide.

\title{
Дифференцировка стволовых клеток костного мозга
}

\section{в нервные клетки-предшественники}

на волокнисто-губчатых конструкциях

для тканевой инженерии периферических нервов

\author{
Т. Дурсун Усал \\ Д. Юкел ${ }^{\text {a, }}$, В. Хасырджи ${ }^{\mathrm{a}, \boldsymbol{0}}$ \\ ${ }^{a}$ Ближневосточный технический университет, BIOMATEN \\ Центр передового опыта в биоматериалах и тканевой инженерии \\ Туриия, 06800, Анкара, бульвар Думлупинар, 1 \\ ${ }^{6}$ Ближневосточный технический университет \\ Факультет биологических наук \\ Туриия, 06800, Анкара, бульвар Думлупинар, 1 \\ ${ }^{6}$ Университет Аджыбадем \\ Туриия, 34752, Стамбул, Атамехир, Ичеренкой Махаллеси, \\ Кампус «Керем Айдынлар», ул. Кайсдаги, 32
}

Стволовые клетки костного мозга (СК КМ) часто используются в исследованиях нервной ткани в связи с легкостью их выделения и высоким потенциалом для дифференцировки в нервные клетки. Двухслойная конструкция из волокон и губки, содержащая нановолоконные элементы для прикрепления СК КМ и их направленной дифференцировки, была разработана в качестве модели для изучения процессов регенерации поврежденной периферической нервной ткани и использования со временем в качестве нервного проводника. Разработанная конструкция состояла из: а) макропористого нижнего слоя, который служил основой и опорой, а также участвовал в переносе питательных веществ, и б) волокнистого верхнего слоя, полученного методом электроспиннинга, для прикрепления клеток и направленной дифференцировки. Пористость и размеры пор нижнего слоя поли-3-гидроксибутирата-3-гидроксивалерата (ПГБВ) составляли $85 \%$ и 5-200 мкм соответственно, что способствовало прикреплению и росту клеток. Ориентация клеток имеет большое значение для межклеточного контакта. 
Степень выравнивания волокон ПГБВ/коллагена составляла $11^{\circ}$ при использовании коллектора типа рамы, и была намного выше (53) для волокон со случайной ориентачией, полученных при сборе на обычный алюминиевый листовой коллектор. Если во время электроспиннинга волокна наносили непосредственно на губку ПГБВ, прикрепленную к коллектору типа рамы чтобы создать двойной слой, степень выравнивания волокон уменьшалась, угол выравнивания увеличивался с 11 до 44․ Когда волокна наносили на губку, закрепленную на алюминиевом листовом коллекторе, степень выравнивания волокон практически не менялась (53 против $55^{\circ}$ ). Была разработана новая среда с иелью достичь дифференцировки клеток, сопоставимой с дифференцировкой в коммерческих средах. Было обнаружено, что коммерческая среда нейрогенной дифференцировки мезенхимальных стволовых клеток (PromoCell, Германия) была лучше с точки зрения экспрессии нейронных маркеров нестина и $\beta$-III тубулина. Результаты экспрессии нейронных маркеров на среде известного состава, полученной в лаборатории, были близки к результатам, полученным на коммерческой среде. Прикрепление и пролиферация СК КМ были выше на волокнах со случайной ориентачией, тогда как выравнивание клеток было лучше на волокнах с упорядоченной ориентацией. Таким образом, было установлено, что двухслойная конструкиия с упорядоченными волокнами ПГБВ/коллаген на губке из ПГБВ более подходит для регенерачии периферических нервов при использовании в качестве нервного проводника.

Ключевые слова: стволовые клетки костного мозга, инженерия нервных тканей, регенерация периферических нервов, нановолоконные маты, нервный проводник.

\section{Introduction}

Peripheral nervous system can be damaged by mechanical, thermal, chemical, or ischemic factors and these damages could result in the disruption of communication between nerve cells and their targets. Proximal and distal nerve stumps created by these incidents are treated by guiding them towards each other using synthetic or biologically derived conduits. In such a case guidance of proximal end towards the distal end is expected to help bridge the gap and thus accelerate healing. Nerve guides with inner guiding elements were reported to be better in terms of guidance of the severed ends of the nerve fibers than those without (Stokols et al., 2006). Combined use of guidance structures and cells (such as Schwann cells) were shown to improve healing ( $\mathrm{Wu}$ et al., 2016).
Electrospinning is widely used to fabricate nano- and microfibrous structures for use in the biomaterials field, and the aligned nanofibers help organize the cells seeded on them to form highly anisotropic tissues such as the nerve, cardiac tissues and muscles. Aligned fibrous structures were shown to be more effective for neuronal differentiation due to their topographical cues for cell elongation (Yang et al., 2005; Yucel et al., 2010; Zhao et al., 2017). Yang et al. (2005) studied the effect of aligned poly(L-lactic acid) (PLLA) nano/micro fibrous scaffolds for neural tissue engineering and showed that the direction of nerve stem cell (NSC) elongation and its neurite outgrowth is parallel to the direction of PLLA fibers for aligned scaffolds (Yang et al., 2005). Researches confirmed that aligned nanofibers have better deformability, slow degradation, comparable porosity and orientation 
cues than random nanofibers. However, studies in the literature mainly focused on the effect of fiber alignment on cell proliferation but not their differentiation. In the present study, differentiation potential of the bone marrow stem cells (rBMSCs) to nerve cells was studied to provide a more feasible cell source than nerve stem cell in the nerve tissue engineering since isolation of BMSCs is much viable and their differentiation potential to nerve cells is very high (Prabhakaran et al., 2009).

The polymer used to prepare the foam and the fibers was a natural polyester, poly(3hydroxybutyrate-co-3-hydroxyvalerate) (PHBV). It is widely used in biomedical applications as sutures, wound dressings, drug delivery, and tissue engineering scaffold material (Arslantunali et al., 2014). The fibrous mats contained also collagen type I to make the scaffold more attractive for cell attachment. Collagen type I is the most abundant collagen type in the nerve tissue (Kaemmer et al., 2010). Furthermore, collagen-based materials was shown to promote neurite outgrowth and the nerve regeneration (Prabhakaran et al., 2013).

In this study, a bilayer fiber-foam construct was produced to create an appropriate microenvironment for the regeneration of damaged peripheral nerves. The bilayer structure consisted of aligned or random fiber mats formed on a sponge substrate layer and electrospinning was designed to study the influence of the organization of the guidance elements on the

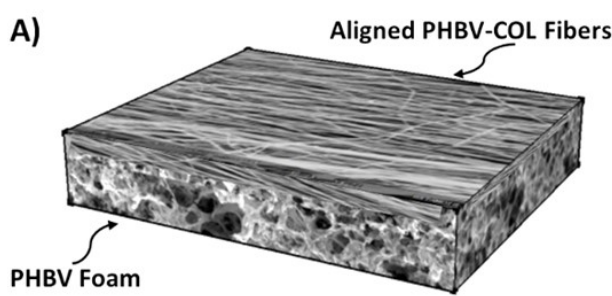

orientation, morphology and differentiation of the rBMSCs seeded. In addition, a novel medium with known contents for optimum differentiation of these cells was designed to make this test system a model system for similar studies. The model system consisting of a bilayer fiber-foam scaffold revealed influence of surface organization on cell orientation, growth, and differentiation of the BMSC into nerve cells.

\section{Methods}

Preparation of the fiber-foam construct

PHBV solution $(5 \%, \mathrm{w} / \mathrm{v}$, in chloroform and dioxane $(2: 3, \mathrm{v} / \mathrm{v}))$ was frozen and lyophilized for $8 \mathrm{~h}$ to prepare the foam component of the bilayer (Fig. 1). The upper layer was either an aligned or a random fibrous mat fabricated by electrospinning adapted from a procedure published earlier by our group (Yucel et al., 2010). In this case, the foam was attached onto the sigmoidal shape collector and electrospun fibers were deposited on the foam. For aligned fibers the collector was a copper plate with parallel grids (Fig. 1A) and for random fibers the collector was an aluminum foil (Fig. 1B). For the fibers, a solution of PHBV/ Collagen $(2: 1,5 \%, w / v)$ in HFIP was electrospun at a flow rate of $4 \mu \mathrm{L} / \mathrm{min}$, a potential of $9 \mathrm{kV}$ using a syringe at a distance of $11 \mathrm{~cm}$.

\section{Characterization of the foams}

The average pore size and pore size distribution were determined by mercury

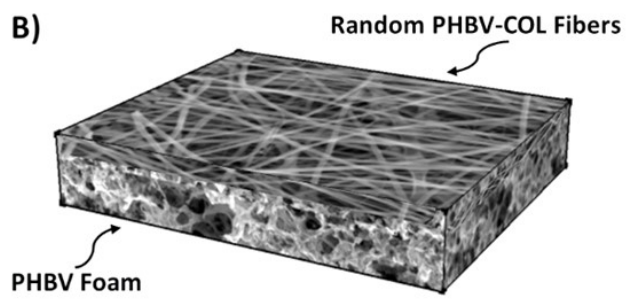

Fig. 1. The fiber-foam construct design. (A) Aligned PHBV/Collagen fibers on PHBV foam, and (B) random PHBV/Collagen fibers on PHBV foam 
porosimetry. The topography of the scaffolds was studied by SEM after coating with gold-palladium. Orientation of the fibers were calculated using Image J program (NIH, USA) from the SEM micrographs.

\section{Isolation and characterization of rBMSCs}

Isolation of rBMSCs was performed according to a procedure developed earlier by our group using a six week old rat (Yilgor et al., 2010). The cell surface antigens investigated were mesenchymal stem cell (MSC) marker CD90, and hematopoietic lineage markers CD45 and CD11b.

\section{Cell seeding}

rBMSCs were suspended and diluted to a concentration of $6 \times 10^{5}$ cells $/ \mathrm{mL}$ in DMEM high glucose tissue culture medium containing penicillin, streptomycin, and 10\% FBS. Aliquots $(50 \mu \mathrm{L})$ of the cell suspension were seeded on scaffolds $\left(150 \times 150 \times 1.7 \mathrm{~mm}^{3}\right)$ so that a cell density of $3 \times 10^{4}$ cells/scaffold was achieved. The cell seeded bilayers were incubated at $37^{\circ} \mathrm{C}$ and $5 \%$ $\mathrm{CO}_{2}$ for $2 \mathrm{~h}$.

\section{Alamar Blue cell proliferation assay}

Samples were washed twice with DMEMhigh glucose colorless medium and incubated in Alamar Blue solution $(1 \mathrm{~mL}, 10 \%$ in DMEMhigh glucose colorless medium) at $37^{\circ} \mathrm{C}$ for $1 \mathrm{~h}$. The supernatant was transferred into 96 well plates, and the absorbances at 570 and $595 \mathrm{~nm}$ were measured. Reductions were calculated according to the Instruction Manual (Invitrogen Inc., USA).

\section{Selection of the differentiation medium}

Three different induction protocols were tested to find the best to differentiate BMSCs into neurons. Protocol 1: BMSCs were cultured in Mesenchymal Stem Cell Neurogenic
Differentiation Medium (Promocell, Germany) for 7 days. Protocol 2: BMSCs were cultured for $24 \mathrm{~h}$ in the preinduction medium (PI, containing $10 \mathrm{ng} / \mathrm{mL}$ Epidermal Growth Factor, $10 \mathrm{ng} / \mathrm{mL}$ basic fibroblast growth factor, $2 \mathrm{mM}$ valproic acid, no FBS). After preinduction, the cells were cultured with neural induction medium (containing $2 \mathrm{mM}$ VA, $50 \mathrm{ng} / \mathrm{mL}$ Insulin-like Growth Factor 1, and 2\% B27, no FBS) for 6 days. Protocol 3: BMSCs were cultured in a PI medium for $24 \mathrm{~h}$, and then Protocol 1 was applied for 6 more days. Differentiation degree of cells was determined by using flow cytometry according to a procedure developed earlier by our group (Sayin et al., 2015).

\section{NSE Determination}

Neuron-Specific Enolase (NSE) is a glycolytic enzyme that catalyzes the conversion of phosphoglycerate to phosphoenolpyruvate and is present in neurons. In order to study its emergence, cells were rinsed with PBS, and incubated overnight at $-20^{\circ} \mathrm{C}$. After two freezethaw cycles and centrifugation the supernatant was tested sample. After incubation for $2 \mathrm{~h}$ at $37^{\circ} \mathrm{C}$ Biotin-NSE antibody solution was added, and samples were incubated for $1 \mathrm{~h}$ at $37^{\circ} \mathrm{C}$. Horse radish peroxidase (HRP)-avidin solution was added, and the samples were incubated for $1 \mathrm{~h}$ at $37^{\circ} \mathrm{C}$. 3,3',5,5'-tetramethylbenzidine (TMB) was added, and the samples were incubated for $30 \mathrm{~min}$ at $37^{\circ} \mathrm{C}$ in the dark. The absorbance of samples at $450 \mathrm{~nm}, 570 \mathrm{~nm}$ and $595 \mathrm{~nm}$ was determined with an Elisa plate reader.

\section{Immunohistochemistry}

The cell seeded scaffolds were fixed with 4\% paraformaldehyde for $15 \mathrm{~min}$, maintained in blocking solution for $1 \mathrm{~h}$, they were incubated overnight at $4{ }^{\circ} \mathrm{C}$ in the primary antibody solution of anti-nestin (1:20 dilution) and then in the secondary antibody solution goat Alexa Fluor 
488-labelled anti-mouse (1:100 dilution), at $37^{\circ} \mathrm{C}$ for $1 \mathrm{~h}$. The samples were studied with CLSM with $488 \mathrm{~nm}$ and $647 \mathrm{~nm}$ lasers for the Alexa Fluors.

\section{Statistical Analysis}

Statistical analyses were performed using a Student's t-test with a minimum confidence level of $95 \%$, p values smaller or equal to 0.05 were considered statistically significant.

\section{Results and discussion}

\section{Characterization of the polymeric scaffolds}

The nerve model was consisted of a foam layer and on top a fibrous layer electrospun. The foam layer was introduced to serve as a carrier for the support cells such as Schwann cells. The fibrous layer would serve as the guidance element to lead the nerve cells to extend parallel to the fibers. SEM micrographs show that the PHBV foams were highly porous with interconnected pores (Fig. 2). The pore size and porosity on the surfaces appeared very uniform (Fig. 2A). The horizontal (Fig. 2B) and vertical cross-sections (Fig. 2C) presented a similar appearance.
Porosity and pore size distribution of the PHBV foams were calculated as $85 \%$ and $5-200 \mu \mathrm{m}$, respectively, with the majority of the pores being in the range 5-20 $\mu \mathrm{m}$ which is in agreement with the optimum pore sizes recommended for proper neovascularization (Dehghani \& Annabi, 2011), for interconnectivity and material transport (ca. $10-20 \mu \mathrm{m})$, and to adhere to and populate the scaffolds (ca. $200 \mu \mathrm{m}$ ).

Fig. 3 shows the SEM of the aligned and random fibers electrospun from a solution of PHBV/Collagen (2:1) deposited directly on the collector and on the foam. NIH ImageJ revealed that the angle of deviation of the random fibers was high, $53^{\circ}$, while for aligned fibers it was very low, $11^{\circ}$ (Table 1 ). As more polymer deposited on the collector, level of alignment decreased due to the reduced conductivity between the grids of the collector and the deposited fibers. A similar observation was made by Yang et al. (2005).

\section{Characterization of rat BMSCs}

Characterization of the cells isolated from rat bone marrow was done with flow cytometry. Cell surface markers investigated were the

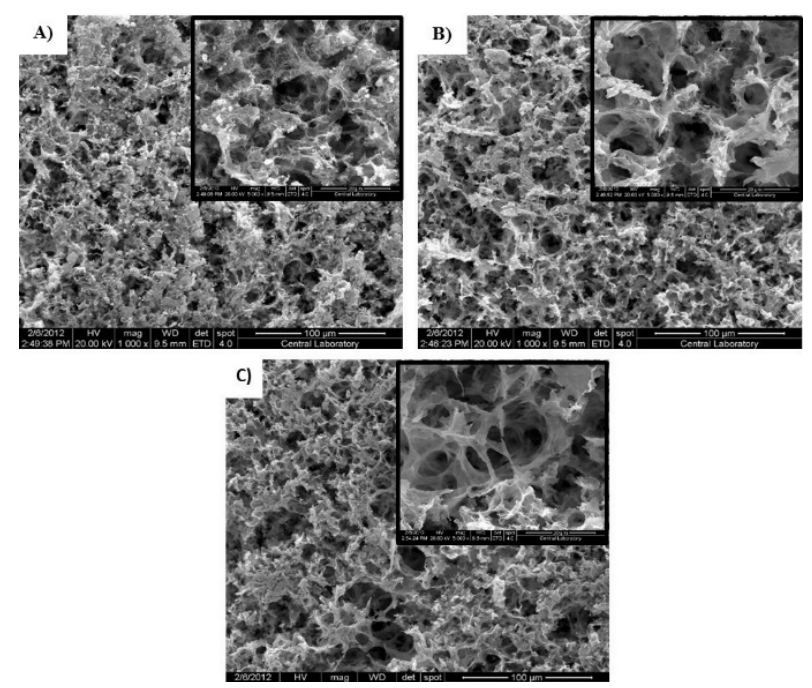

Fig. 2. SEM of PHBV foam. (A) the top surface, (B) the horizontal cross-section, and (C) the vertical cross-section (Magnifications x1,000, Inset x5,000) 


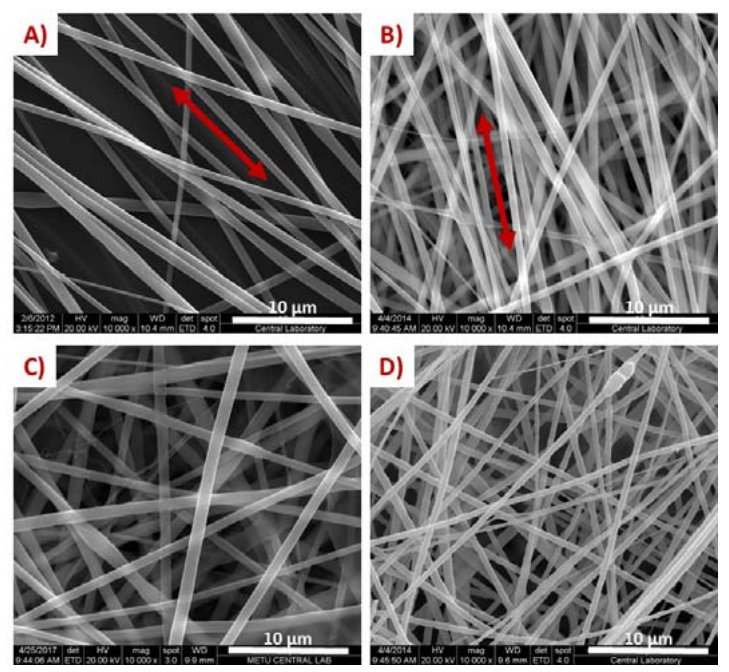

Fig. 3. Comparison of the degree of alignment of PHBV/Collagen fibers obtained by electrospinning. (A) fibers electrospun on the frame collector, (B) fibers electrospun on the frame collector with foam, (C) fibers electrospun on the Al foil collector, (D) fibers electrospun on Al foil with the foam. Magnification: x10,000

Table 1. Degree of alignment of fibers formed on frame and Al foil collectors with and without underlying foam

\begin{tabular}{|c|c|c|}
\hline Collector & \multicolumn{2}{|c|}{ Degree of Alignment } \\
& Frame $\left(^{\circ}\right)$ & Al Foil $\left(^{\circ}\right)$ \\
\hline Without foam & 11 & 53 \\
With foam & 44 & 55 \\
\hline
\end{tabular}

mesenchymal stem cell marker CD90 and the hematopoietic lineage markers CD45 and CD11b. The fluorescence intensities (FI) of the control groups were low and similar (Fig. 4A) indicating that their choice is appropriate. Signal of the positive cells were compared with those of their control groups. Fig. 4B shows that anti-CD90 has a significant peak with a high FI $\left(10^{5}\right)$, and while those of the controls were much lower (FI 10 3 ). Anti-CD45 and anti-CD11b FI were as low as the controls, indicating that isolated BMSCs did not have blood cell lineage, and were suitable for use as stem cells to differentiate into neurons.

\section{Cell proliferation on the bilayer scaffolds}

Proliferation of rBMSCs on the bilayer scaffolds was studied with the Alamar Blue assay. Day 1 data show that attachment efficiencies of cells on aligned and random fibers produced on foam substrates are similar and the number of attached rBMSCs $\left(2.5 \times 10^{4}\right.$ cells $)$ are close to the cell seeding density (Fig. 5). The population doubling time of BMSCs is about 4 days (Lotfy et al., 2014) and the increase in cell numbers is very robust, especially on the random fiber scaffolds; they almost doubled between the Days 4 and 7. It should also be taken into consideration that the medium used was a differentiation medium in which proliferation is generally slower.

Alamar Blue Assay revealed that more cells grew on RF-Fo (Al foil collector), the random fiber constructs than on aligned AF-Fo (frame collector) constructs. It was reported similar results with Schwann cells seeded on polycaprolactone/gelatin (PCL/gelatin) fibers 
A)

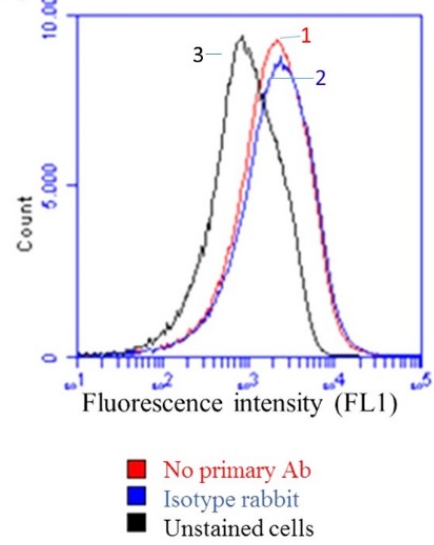

B)

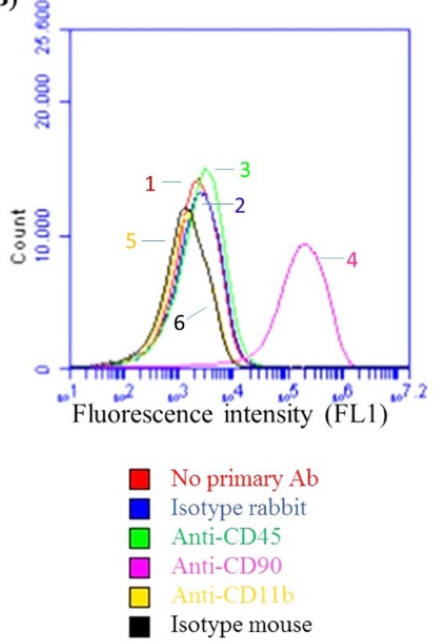

Fig. 4. Flow cytometry of rBMSC P2 after incubation in DMEM-high glucose medium containing penicillin, streptomycin. Fluorescence intensities of (A) controls, and (B) the samples for the stem cell marker CD90, and hematopoietic markers CD45, and CD11b

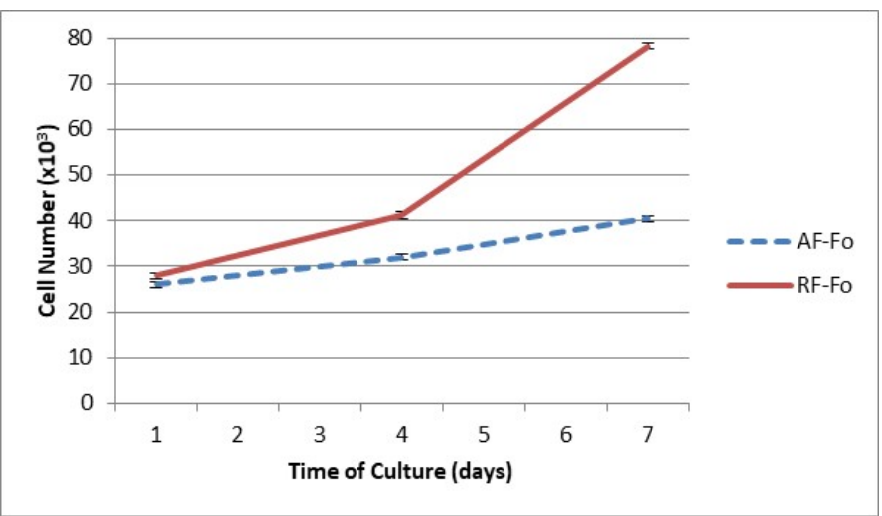

Fig. 5. Proliferation of rat bone marrow stem cells (rBMSCs) on bilayer AF-Fo, and RF-Fo scaffolds as determined by Alamar Blue Assay. Cell seeding density: 3x10 4 cells/scaffold. Medium: Neuronal differentiation medium

(Yang et al., 2005). They explained this by the random fiber mats having larger gaps between the fibers that allowed cell penetration into the mat while the aligned mats did not. In nerve regeneration, orientation of the cells is more important than proliferation, and in the present case the aligned fibers induced the cells to align parallel to the fibers and to each other and thus appear to be the better surface. Even though cell proliferation was slow on the aligned fiber scaffolds, the cell number still increased ca. 1.5 fold during the 7 days following the seeding. These all show that the aligned bilayer structures are promising for use in nerve regeneration, and therefore, a complete tubular form could be constructed and tested as a nerve guide in vivo, too.

\section{Cell alignment on the fibrous mats}

Fluorescence microscopy revealed that cells on AF-Fo samples were aligned (Fig. 6A) on Day 16, meanwhile, on the RF-Fo construct 

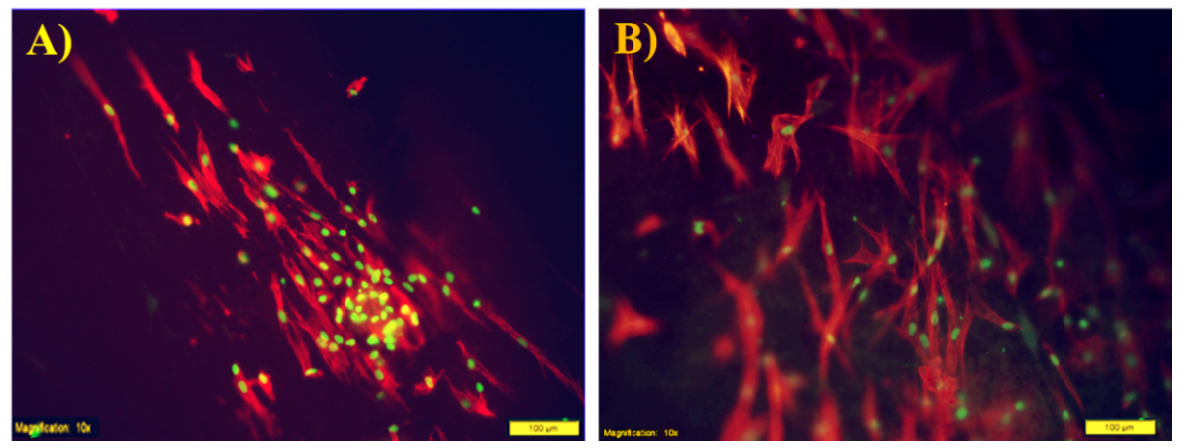

Fig. 6. Fluorescence micrographs of rBMSCs seeded on fiber-foam bilayer constructs. (A) Aligned fiber-foam (AF-Fo), and (B) random fiber-foam (RF-Fo). Staining: Alexa Fluor 532-Phalloidin (red) for cytoskeleton, and DAPI (green) for the nucleus. Day 16. Scale bars: $100 \mu \mathrm{m}$. Medium: Normal growth medium
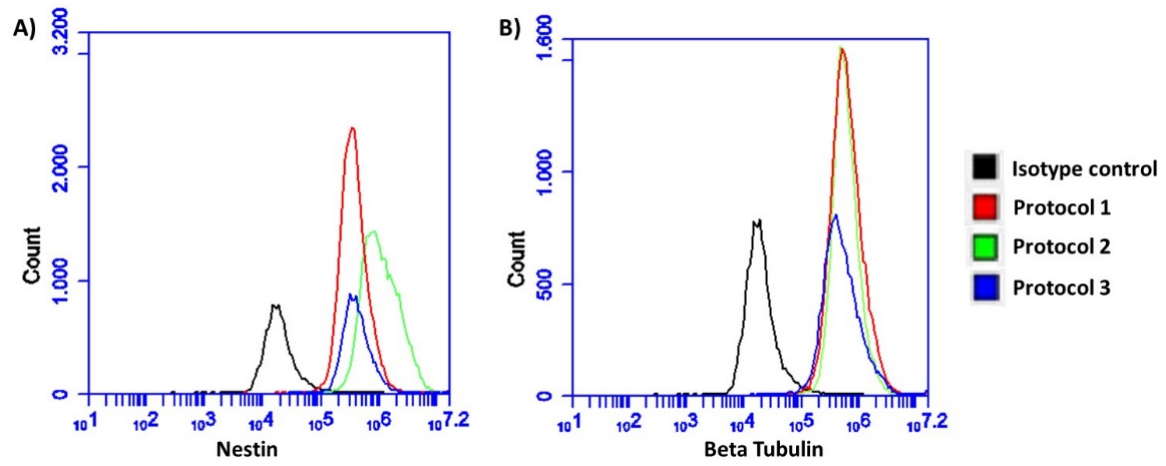

Fig. 7. Expression of nestin and $\beta$-tubulin after differentiation studies. (A) Expression of nestin with isotype control and three different differentiation protocols, (B) Expression of $\beta$-tubulin with isotype control and three different differentiation protocols

there was no alignment; they extended in all directions as expected (Fig. 6B). Cells were seen to form contacts with each other. Standard deviation on the aligned fibers was found to be $11^{\circ}$ and much higher on random fibers $\left(53^{\circ}\right)$. It was reported earlier that aligned polymer fiberbased facilitate the regeneration of peripheral nerves across long nerve gaps (Prabhakaran et al., 2013). Significantly aligned fibers enhance regeneration, establishing that topographical cues can influence endogenous nerve repair mechanisms in the absence of exogenous growth promoting proteins. Shape of cells on the aligned fibers were more elliptical due to extending along the fibers. On the random fibers, cells stayed in a more circular shape.
rBMSC differention studies on fiber-foam constructs and comparison of the differentiation media

The effectiveness of the 3 different media for the induction of differentiation of rBMSCs into neuronal cells was assessed with flow cytometry (Fig. 7). Foudah et al. (2012) stated that the level of expression of neuronal markers could decrease with passage number, therefore, rBMSCs passages 1-3 were used.

In Protocol 1 high levels of expression of the neuronal markers nestin and beta III-tubulin (FI: 1,442.302 and 710.289, respectively) were observed. Protocol 2 led to a lower expression of nestin and similar expression of beta III-tubulin 
compared to Protocol 1 (FI 510.985 and 701.995, respectively). In Protocol 3 the expression of nestin (FI: 451.226) was lower than those obtained in Protocol 1 that did not include the PI step. Beta III-tubulin expression (FI: 782.935) was slightly higher than those obtained with Protocol 1.

Table 2 summarizes the FI values of nestin and beta III-tubulin with isotype control and the 3 protocols. When compared, very similar expressions of beta III-tubulin are seen. Even though the highest expression of nestin was achieved with Protocol 1, Protocols 2 and 3 also had significant amounts of nestin expression. Furthermore, the composition of commercial medium used in Protocol 1 is not revealed while with Protocol 2 the ingredients are known. Protocol 2 could be preferred for use in neuronal differentiation due to its known composition.

Even though Protocol 2 is an open source medium, Protocol 1 was used in the rest of the experiments because its being a simpler, one step differentiation process and also because of the higher expression of nestin and beta III-tubulin. After the selection of the medium rBMSCs were seeded on the fiber-foam bilayer constructs.

Immunochemistry was performed for NSE and nestin to study and compare the differentiation level of these cells. NSE appears at the onset of neurogenesis and continues to increase well after neurogenesis ends, during the period of early neuronal differentiation
(Jørgensen \& Centervall, 1982). It was observed that NSE levels of the rBMSC seeded on both scaffolds were distinctly higher when cultured in the differentiation medium, proving that the rBMSCs were differentiated into neurons on the bilayer fiber-foam constructs (Table 3).

Fig. 8 shows the nestin expression of cells in normal and in differentiation medium. Expression of nestin was higher for the cells cultured in the differentiation medium on both aligned and the random fibers. CLSM results showed that both surfaces are suitable for rBMSC differentiation. The increase in nestin expression of cells cultured according to Protocol 1 is distinctly higher than in normal medium. Results of immunostaining are consistent with flow cytometry. The results show that rBMSC can be used in nerve tissue engineering applications by inducing them to differentiate into neurons using appropriate differentiation media.

\section{Conclusions}

In this study, PHBV/Collagen fiber-foam constructs were prepared to create a scaffold with appropriate cell guidance elements in order to improve the performance in in vitro nerve regeneration models and in vivo studies and with the choice of an appropriate differentiation medium for the induction of differentiation of BMSCs into nerve cells. During peripheral nerve regeneration after a trauma, the axons

Table 2. Mean fluorescence intensities (MFI) of nestin and beta III-tubulin with isotype control, undifferentiated rBMSCs and three different differentiation protocols

\begin{tabular}{|c|c|c|}
\hline & MFI of nestin & MFI of beta tubulin \\
\hline Isotype control & 25.810 & 25.810 \\
Undifferentiated rBMSCs & 301.818 & 282.460 \\
Differentiation w/Prot. 1 & 1.442 .302 & 710.289 \\
Differentiation w/Prot. 2 & 510.985 & 701.995 \\
Differentiation w/Prot. 3 & 451.226 & 782.935 \\
\hline
\end{tabular}



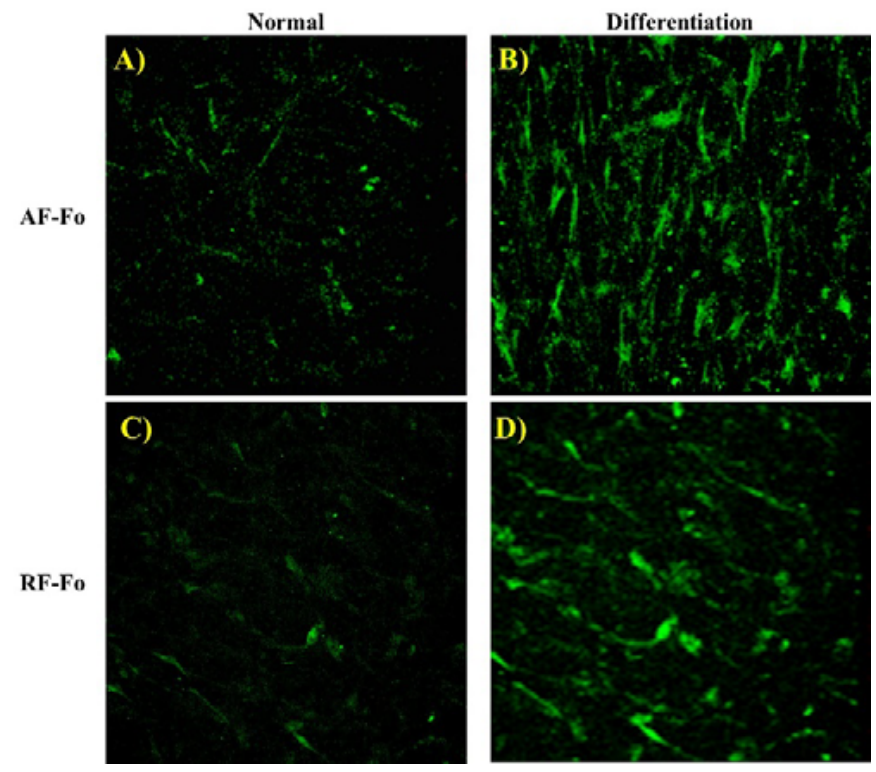

Fig. 8. Differentiation and expression of nestin (green) by rBMSCs grown on AF-Fo (A, B) and on RF-Fo (C, D). (A) AF-Fo, Normal medium, (B) AF-Fo, Neurogenic Differentiation Medium. (C) RF-Fo, Normal medium, (D) RF-Fo, Neurogenic Differentiation Medium (Differentiation Protocol 1). Culture duration: 7 days

Table 3. NSE expression by undifferentiated and differentiated cells on AF-Fo and RF-Fo bilayer scaffolds after 7 days of incubation

\begin{tabular}{|c|c|}
\hline Sample & NSE level (ng/mL) \\
\hline Undifferentiated rBMSCs & $0.07 \pm 0.01$ \\
rBMSCs differentiated on AF-Fo bilayer scaffold & $1.10 \pm 0.02$ \\
rBMSCs differentiated on RF-Fo bilayer scaffold & $1.21 \pm 0.04$ \\
\hline
\end{tabular}

within a hollow lumen generally exhibit random and disorganized outgrowth, and fail to align in unison with the linear descending and ascending tracts. The function of the electrospun fibers is to guide the cells during this process. In order to study the effectiveness of the bilayer constructs to guide the cells, two different scaffolds, with an aligned and a random fibrous structure formed on a foam (sponge) were tested. The foam was to allow crosstalk between the support cells (which could be seeded outside a tubular nerve guide) and the nerve cells on the inside, without allowing cell-to-cell contact. Characteristic properties of the scaffolds such as porosity, pore sizes were suitable for cell attachment and growth. It was possible to proliferate and align the rBMSCs and induce to differentiate into nerve cells. In conclusion, this construct has a high potential for use in vivo in peripheral nerve regeneration studies.

\section{Acknowledgements}

We acknowledge the support by METU (BAP 07.02.2012-101) and METU CoE in Biomaterials and Tissue Engineering (BIOMATEN). We also gratefully acknowledge the Ministry of Development of Turkey (BAP 01.08.DPT.2003K120920-20) and the Scientific and Technological Research Council of Turkey (2205 BIDEP-TUBITAK Fellowship for TD). 


\section{References}

Arslantunali D., Dursun T., Yucel D., Hasirci N., Hasirci V. (2014) Peripheral nerve conduits: technology update. Medical Devices: Evidence and Research, 7: 405-424

Dehghani F., Annabi N. (2011) Engineering porous scaffolds using gas-based techniques. Current Opinion in Biotechnology, 22(5): 661-666

Foudah D., Redondo J., Caldara C., Carini F., Tredici G., Miloso M. (2012) Expression of neural markers by undifferentiated rat mesenchymal stem cells. Journal of Biomedicine and Biotechnology, 2012: 9-14

Jørgensen O.S., Centervall G. (1982) ??-Enolase in the rat: ontogeny and tissue distribution. Journal of Neurochemistry, 39(2): 537-542

Kaemmer D., Bozkurt A., Otto J., Junge K., Klink C., Weis J., Sellhaus B., O'Dey D.M., Pallua N., Jansen M., Schumpelick V., Klinge U. (2010) Evaluation of tissue components in the peripheral nervous system using Sirius red staining and immunohistochemistry: a comparative study (human, pig, rat). Journal of Neuroscience Methods, 190(1): 112-116

Lotfy A., Salama M., Zahran F., Jones E., Badawy A., Sobh M. (2014) Characterization of mesenchymal stem cells derived from rat bone marrow and adipose tissue: a comparative study. International Journal of Stem Cells, 7(2): 135-142

Prabhakaran M.P., Vatankhah E., Ramakrishna S. (2013) Electrospun aligned PHBV/collagen nanofibers as substrates for nerve tissue engineering. Biotechnology and Bioengineering, 110(10): $2775-2784$

Prabhakaran M.P., Venugopal J.R., Ramakrishna S. (2009) Mesenchymal stem cell differentiation to neuronal cells on electrospun nanofibrous substrates for nerve tissue engineering. Biomaterials, 30(28): 4996-5003

Sayin E., Baran E.T., Hasirci V. (2015) Osteogenic differentiation of adipose derived stem cells on high and low aspect ratio micropatterns. Journal of Biomaterials Science, Polymer Edition, 26(18): $1402-1424$

Stokols S., Sakamoto J., Breckon C., Holt T., Weiss J., Tuszynski M.H. (2006) Templated agarose scaffolds support linear axonal regeneration. Tissue Engineering, 12(10): 2777-2787

Wu Y., Wang L., Guo B., Shao Y., Ma P.X. (2016) Electroactive biodegradable polyurethane significantly enhanced Schwann cells myelin gene expression and neurotrophin secretion for peripheral nerve tissue engineering. Biomaterials, 87: 18-31

Yang F., Murugan R., Wang S., Ramakrishna S. (2005) Electrospinning of nano/micro scale poly(l-lactic acid) aligned fibers and their potential in neural tissue engineering. Biomaterials, 26(15): 2603-2610

Yilgor P., Hasirci N., Hasirci V. (2010) Sequential BMP-2/BMP-7 delivery from polyester nanocapsules. Journal of Biomedical Materials Research Part A, 93(2): 528-536

Yucel D., Kose G.T., Hasirci V. (2010) Polyester based nerve guidance conduit design. Biomaterials, 31(7): 1596-1603

Zhao Y., Gong J., Niu C., Wei Z., Shi J., Li G., Yang Y., Wang H. (2017) A new electrospun graphene-silk fibroin composite scaffolds for guiding Schwann cells. Journal of Biomaterials Science, Polymer Edition, 28(18): 2171-2185 